\title{
Sovereign Wealth Funds Definition: Challenges and Concerns
}

\author{
Zeineb Ouni $^{1, *}$, Prosper Bernard ${ }^{2}$, Michel Plaisent ${ }^{2}$ \\ ${ }^{1}$ Department of Finance and Economics, School of Management, University of Quebec in Trois-Rivières, \\ Trois-Rivières, Quebec, Canada \\ ${ }^{2}$ Department of Management, School of Sciences and Management, University of Quebec at Montreal, Montreal, Quebec, Canada
}

Received August 18, 2020; Revised October 13, 2020; Accepted October 19, 2020

\section{Cite This Paper in the following Citation Styles}

(a): [1] Zeineb Ouni, Prosper Bernard, Michel Plaisent, "Sovereign Wealth Funds Definition: Challenges and Concerns," Advances in Economics and Business, Vol. 8, No. 6, pp. 362 - 376, 2020. DOI: 10.13189/aeb.2020.080605.

(b): Zeineb Ouni, Prosper Bernard, Michel Plaisent (2020). Sovereign Wealth Funds Definition: Challenges and Concerns. Advances in Economics and Business, 8(6), 362 - 376. DOI: 10.13189/aeb.2020.080605.

Copyright $\bigcirc 2020$ by authors, all rights reserved. Authors agree that this article remains permanently open access under the terms of the Creative Commons Attribution License 4.0 International License

\begin{abstract}
The main purpose of this paper is to bring a better understanding of the phenomenon of sovereign wealth funds (SWFs) by dealing with their definitional issues. Our objective is to understand why it would be difficult to have a standard and common definition of SWFs and how this definition concern could present a problem, especially for academic research. We analyzed the history of SWFs, their creation objectives, their sources of funding, the performance of their investments and their governance structure and compared them with other types of funds. We find that the lack of a common definition stems mainly from their: $i$ ) hybrid nature: SWFs are created and controlled by governments, but their investment strategies are similar to private funds; ii) high heterogeneity: SWFs have different structures, sources of funding and other creation objectives; iii) lack of transparency. Despite the establishment of Generally Accepted Principles and Practices for SWFs know as Santiago Principles, SWFs remain opaque structure and iv) similarities with other sovereign and private investors, especially in their investment strategies. These definitional problems could explain the lack of consensus on empirical studies about SWFs and the issues about the regulation of their activities. Otherwise, this study targets to contribute to the global debate on the regulation of their transactions, essentially by clarifying their subtle differences with other investment vehicles.
\end{abstract}

Keywords Sovereign Wealth Funds, Sovereign Investors, Definitional Issues

JEL Codes F21, F30, G23, G29, N20

\section{Introduction}

SWFs have received extensive publicity and increasing attention in recent years. These funds, not previously well known, are emerging as significant players in the international financial markets. They are growing both in size and number. According to the Sovereign Wealth Fund Institute (SWFI), the size of SWFs in 2020 exceeds US\$8 trillion, a considerable size compared to other investment vehicles such as hedge funds, which account for US\$2.8 trillion. Over 70\% of existing SWFs were created during the 2000s. The increase in oil prices and the accumulation of currency reserves representing their significant financing sources explain this rapid growth.

SWFs (also known as national wealth funds) are investment vehicles created and controlled by their sovereign states. Hence the name of SWFs, a term first introduced by Rozanov [1] in 2005. Their creation's objectives may depend on their countries of origin's economic, political, and social conditions. For example, oil-rich countries like those in the Persian Gulf region establish SWFs to invest excess oil revenues to ensure future generations' wealth. Other countries develop stabilization funds to protect themselves against currency volatility and put their economy's dependence on oil revenues into perspective (for example, Venezuela), while others (like Norway) create SWFs to deal with an aging population or to promote a model of society. 
SWFs represent a unique type of investment that cannot be compared with other government or private investment vehicles. Their specificity stems from the fact that they combine the governmental nature with private investment strategies. Moreover, the rise of SWFs has favored the emergence of the concept of state capitalism. The development of this concept has raised concerns, especially after the success of privatization movements in the 1990s, and has provoked continued criticism for state intervention in the business world. For all these reasons, SWFs continue to generate debates about their investment objectives, their impact on the host countries' sovereignty, and the financial markets' stability. These debates have been going on for years, and SWFs are still controversial and misunderstood. This phenomenon has raised questions still unresolved. Until now, it is challenging to say explicitly: who exactly are SWFs, how are they governed, what their fundamental objectives are, what their investment strategy is, how they can be distinguished from other investment vehicles, etc. We aim to participate in this debate and to bring a better understanding of this phenomenon; to achieve this, it would be essential to trace their history and analyze the economic and political landscape around them. In the following paragraphs, the focus will be on the issues of the definition of SWFs. We will provide an overview of their history and foundation, their creation objectives, investment strategies, and their challenges.

\section{Sovereign Wealth Funds Foundations: The Rise of State Capitalism}

To better understand SWFs, it is essential to start with a presentation of their history and the context in which they appeared. SWFs were born at least half a century ago ([2, 3]). Historically, the first fund was created in 1854 in the United States (Texas Permanent School Fund). However, the creation of SWFs in their modern form started in the 1950s, in particular by commodities-rich countries such as Saudi Arabia in 1952 (SAMA Foreign Holdings), Kuwait in 1953 (Kuwait Investment Authority), and Kiribati in 1956 (Revenue Equalization Reserve Fund). Table 1 provides a list of the largest SWFs by assets under management. the country of origin of the SWFs, their assets in billions of US\$, their sources of funding and the date of their inception.

Table 1. Sovereign Wealth Fund Rankings by Total Assets

\begin{tabular}{|c|c|c|c|}
\hline Sovereign Wealth Fund Name & Country & Sources of funding & Year of Inception \\
\hline Norway Government Pension Fund Global & Norway & Commodity & 1990 \\
\hline China Investment Corporation & China & No-Commodity & 2007 \\
\hline Abu Dhabi Investment Authority & $\mathrm{UAE}^{\mathrm{a}}$ & Commodity & 1976 \\
\hline Kuwait Investment Authority & Kuwait & Commodity & 1953 \\
\hline Hong Kong Monetary Authority Investment Portfolio & Hong Kong & No-Commodity & 1993 \\
\hline Saudi Arabian Monetary Agency & Saudi Arabia & Commodity & 1952 \\
\hline GIC Private Limited & Singapore & No-Commodity & 1981 \\
\hline SAFE Investment Company & China & No-Commodity & 1997 \\
\hline Temasek Holdings & Singapore & No-Commodity & 1974 \\
\hline Public Investment Fund & Saudi Arabia & Commodity & 2008 \\
\hline National Council for Social Security Fund & China & No-Commodity & 2000 \\
\hline Qatar Investment Authority & Qatar & Commodity & 2005 \\
\hline Investment Corporation of Dubai & UAE & No-Commodity & 2006 \\
\hline Mubadala Investment Company & UAE & Commodity & 2002 \\
\hline Turkey Wealth Fund & Turkey & No-Commodity & 2016 \\
\hline National Welfare Fund & Russia & Commodity & 2008 \\
\hline Korea Investment Corporation & South Korea & No-Commodity & 2005 \\
\hline Abu Dhabi Investment Council & UAE & Commodity & 2007 \\
\hline Dubai World & UAE & No-Commodity & 2006 \\
\hline Future Fund & Australia & No-Commodity & 2006 \\
\hline National Development Fund of Iran & Iran & Commodity & 2011 \\
\hline Alberta Investment Management Corporation & Canada & Commodity & 1976 \\
\hline Samruk-Kazyna & Kazakhstan & No-Commodity & 2008 \\
\hline Alaska Permanent Fund Corporation & United States & Commodity & 1976 \\
\hline
\end{tabular}


Table 1 Continuous

\begin{tabular}{|c|c|c|c|}
\hline Kazakhstan National Fund & Kazakhstan & Commodity & 2000 \\
\hline Brunei Investment Agency & Brunei & Commodity & 1983 \\
\hline Libyan Investment Authority & Libya & Commodity & 2006 \\
\hline International Petroleum Investment Company & UAE & Commodity & 1981 \\
\hline University of Texas Investment Management Company & United States & Commodity & 1876 \\
\hline Texas Permanent School Fund & United States & Commodity & 1854 \\
\hline Emirates Investment Authority & UAE & Commodity & 2007 \\
\hline State Oil Fund of Azerbaijan & Azerbaijan & Commodity & 1999 \\
\hline CNIC Corporation Limited & Hong Kong & No-Commodity & 2012 \\
\hline New Zealand Superannuation Fund & New Zealand & No-Commodity & 2002 \\
\hline Hong Kong Future Fund & Hong Kong & No-Commodity & 2016 \\
\hline Nuclear Waste Disposal Fund & Germany & No-Commodity & 2017 \\
\hline Austrian State and Industrial Holding Limited & Austria & No-Commodity & 2015 \\
\hline New Mexico State Investment Council & United States & Commodity & 1958 \\
\hline Khazanah nasional Berhad & Malaysia & No-Commodity & 1993 \\
\hline Fund for Reconstruction and Development of Uzbekistan & Uzbekistan & NA & 2006 \\
\hline Mumtalakat Holding & Bahrain & No-Commodity & 2006 \\
\hline State General Reserve Fund & Oman & Commodity & 1980 \\
\hline Ireland Strategic Investment Fund & Ireland & No-Commodity & 2001 \\
\hline Timor-Leste Petroleum Fund & East Timor & Commodity & 2005 \\
\hline Economic and Social Stabilization Fund & Chile & NA & NA \\
\hline Social and Economic Stabilization Fund & Chile & Commodity & 2007 \\
\hline Russian Direct Investment Fund & Russia & No-Commodity & 2011 \\
\hline Sovereign Fund of Egypt & Egypt & NA & 2018 \\
\hline Chile Pension Reserve Fund & Chile & Commodity & 2006 \\
\hline National Pensions Reserve Fund & Ireland & No-Commodity & 2009 \\
\hline Solidium & Finland & No-Commodity & 1991 \\
\hline Mexico Budgetary Income Stabilization Fund & Mexico & NA & NA \\
\hline Revenue Regulation Fund & Algeria & Commodity & 2000 \\
\hline Permanent Wyoming Mineral Trust Fund & United States & Commodity & 1974 \\
\hline NSW Generations Fund & Australia & NA & 2018 \\
\hline Fundo Soberano do Brasil (FSB) & Brazil & No-Commodity & 2008 \\
\hline CDP Equity & Italy & No-Commodity & 2011 \\
\hline North Dakota Legacy Fund & United States & Commodity & 2011 \\
\hline Heritage and Stabilization Fund & $\begin{array}{|ll|}\text { Trinidad } & \& \\
\text { Tobago } & \\
\end{array}$ & Commodity & 2000 \\
\hline Oil Revenues Stabilization Fund & Mexico & Commodity & 2000 \\
\hline Oman Investment Fund & Oman & Commodity & 2006 \\
\hline Fiscal Stabilization Fund & Peru & No-Commodity & 1999 \\
\hline China-Africa Development Fund & China & No-Commodity & 2007 \\
\hline Pula Fund & Botswana & Commodity & 1994 \\
\hline Colombia Savings and Stabilization Fund & Colombia & Commodity & 2011 \\
\hline Alabama Trust Fund & United States & Commodity & 1985 \\
\hline SFPI-FPIM & Belgium & No-Commodity & 2006 \\
\hline Utah SITFO & United States & Commodity & 1896 \\
\hline Fundo Soberano de Angola & Angola & Commodity & 2012 \\
\hline
\end{tabular}


Table 1 Continuous

\begin{tabular}{|c|c|c|c|}
\hline Ras Al Khaimah Investment Authority & UAE & Commodity & 2000 \\
\hline Idaho Endowment Fund Investment Board & United States & Commodity & 1969 \\
\hline Nigeria Sovereign Investment Authority & Nigeria & Commodity & 2012 \\
\hline Bayelsa Development and Investment Corporation & Nigeria & No-Commodity & 2012 \\
\hline Fondo de Ahorro de Panama & Panama & No-Commodity & 2012 \\
\hline Hellenic Corporation of Assets and Participations & Greece & No-Commodity & 2011 \\
\hline Taiwan national Stabilization Fund & Taiwan & NA & 2000 \\
\hline Louisiana Education Quality Trust Fund & United States & Commodity & 1986 \\
\hline Oklahoma Tobacco Settlement Endowment Trust & United States & No-Commodity & 2001 \\
\hline Fund for Productive Industrial Revolution & Bolivia & No-Commodity & 2012 \\
\hline Senegal FONSIS & Senegal & No-Commodity & 2012 \\
\hline Development Fund for Iraq & Iraq & Commodity & 2003 \\
\hline Palestine Investment Fund & Palestine & No-Commodity & 2003 \\
\hline Colorado Public School Fund Investment Board & United States & No-Commodity & NA \\
\hline Sharjah Asset Management & UAE & No-Commodity & 2008 \\
\hline Kiribati Revenue Equalization Reserve Fund & Kiribati & Commodity & 1956 \\
\hline National Development and Social Fund & Malta & No-Commodity & 2015 \\
\hline State Capital Investment Corporation & Vietnam & No-Commodity & 2005 \\
\hline Ghana Heritage Fund & Ghana & Commodity & 2011 \\
\hline Ghana Stabilization Fund & Ghana & NA & 2011 \\
\hline Native Hawaiian Trust Fund & United States & NA & NA \\
\hline Fiscal Stability Fund & Mongolia & Commodity & 2011 \\
\hline National Fund for Hydrocarbon Reserves & Mauritania & Commodity & 2006 \\
\hline Western Australian Future Fund & Australia & Commodity & 2012 \\
\hline Luxembourg Intergenerational Sovereign Fund & Luxembourg & No-Commodity & 2014 \\
\hline Iran Oil Stabilization Fund & Iran & Commodity & 2011 \\
\hline Ontario First nations Sovereign Wealth & Canada & Commodity & 2018 \\
\hline Agaciro Development Fund & Rwanda & NA & 2012 \\
\hline Mongolia Future Heritage Fund & Mongolia & NA & NA \\
\hline Sovereign Fund of the Gabonese Republic & Gabon & Commodity & 1998 \\
\hline Tuvalu Trust Fund & Australia & NA & 1987 \\
\hline Petroleum Investment Fund Uganda & Uganda & Commodity & 2015 \\
\hline National Investment Corporation & Kazakhstan & Commodity & 2012 \\
\hline Fund for Future Generations & \begin{tabular}{|l|} 
Equatorial \\
Guinea \\
\end{tabular} & Commodity & 2002 \\
\hline Bhutan Economic Stabilization Fund & Bhutan & NA & NA \\
\hline Fondo Mexicanao del Petroleo & Mexico & Commodity & 2014 \\
\hline Cyprus National Investment Fund & Cyprus & NA & NA \\
\hline Israeli Citizens Fund & Israel & NA & NA \\
\hline Mubadala Development Company PJSC & UAE & NA & NA \\
\hline Qatar Investment Office & Qatar & NA & NA \\
\hline Saudi Technology Development and Investment Company (Taqnia) & Saudi Arabia & NA & NA \\
\hline Sentosa Development Corporation & Singapore & NA & 1972 \\
\hline \multicolumn{4}{|l|}{ Total commodity } \\
\hline \multicolumn{4}{|l|}{ Total non-commodity } \\
\hline Total & & & \\
\hline
\end{tabular}

Source: Sovereign Wealth Fund Institute (Updated July 2020)

${ }^{a} U A E$ : United Arab Emirates 


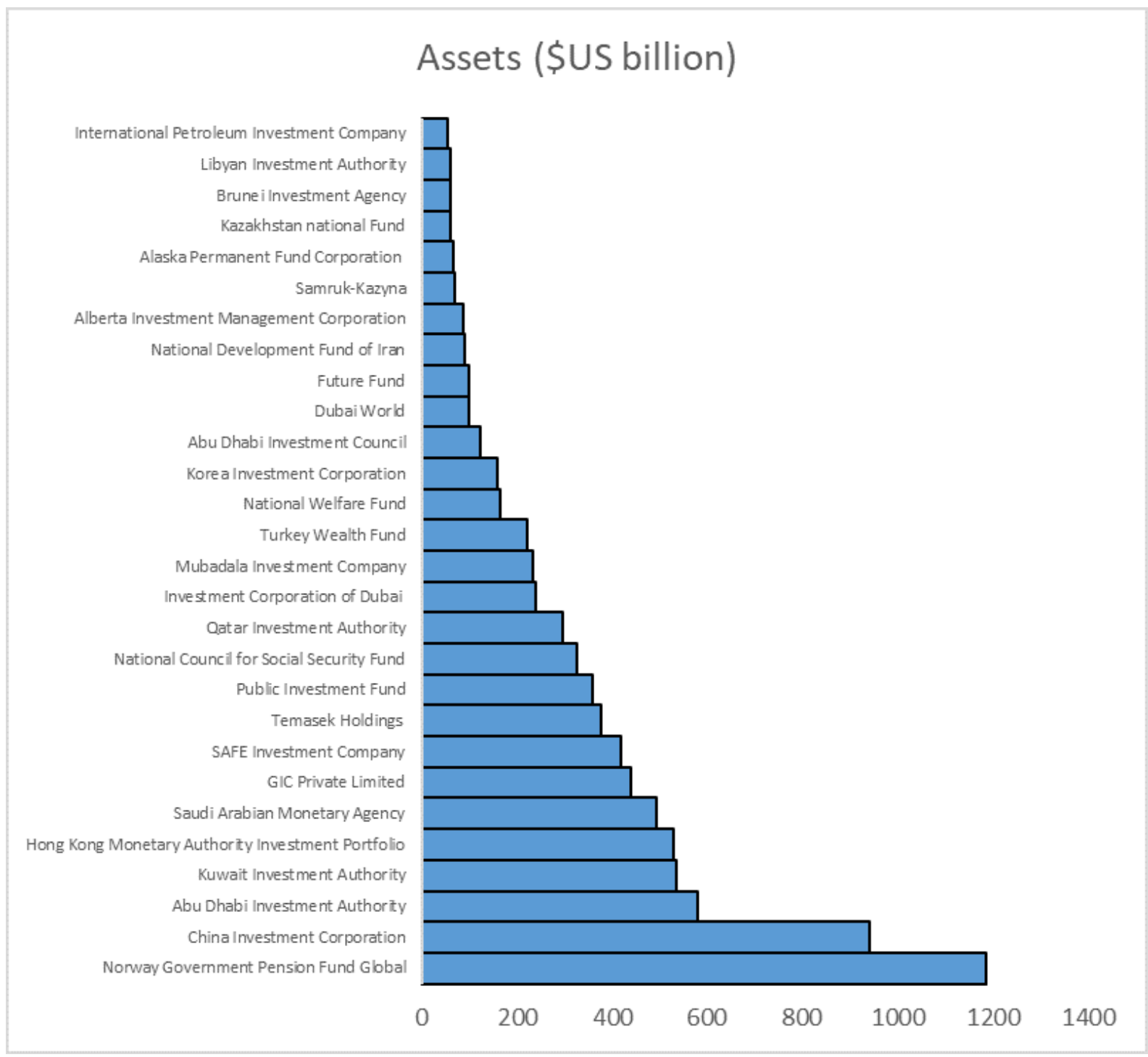

Figure 1. Largest Sovereign Wealth Funds by Assets Under management (Source, author's calculations based on SWFI data updated on July 2020)

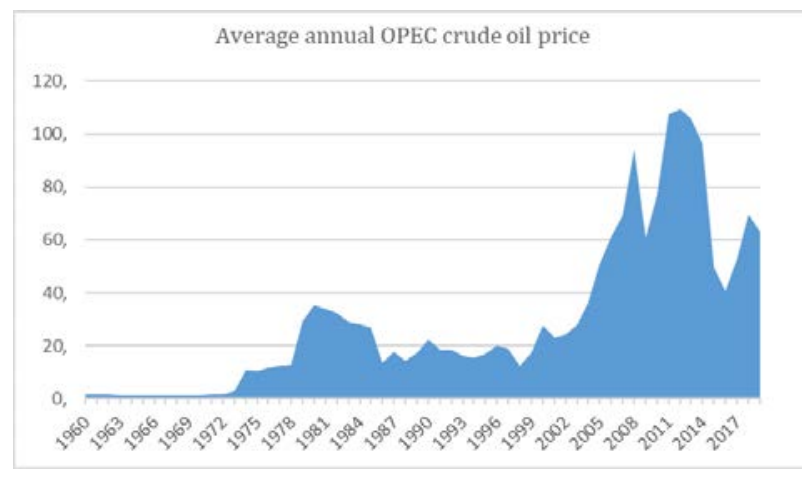

Figure 2. Historical oil prices (Source, Statista 2020)

These funds were primarily created during the post-World War II period when the oil price rose due to the increasing demand for automobiles and production fluctuations in the United States. The largest commodity SWFs by asset under management are the Government Pension Fund of Norway in 1990 and the Abu Dhabi
Investment Authority in 1976 (Figure 1). As illustrated in Figure 2, the explosion of oil prices after the Suez Canal crisis, the embargo of the Arab oil-producing countries against the countries which support Israel in the Yom Kippur War ${ }^{1}$, the fall of production and export of oil during the Iranian revolution (1978-1979), and the conflict between Iraq and Iran in the early 1980s explain the creation of these funds. During the same period, developed and emerging countries such as Canada, Norway, China, Malaysia, and Singapore created a new generation of funds. Following a substantial accumulation of currency reserves ${ }^{2}$, the emerging Asian countries launched their SWFs like, for example, the Khazanah Nasional Berhad in Malaysia and the SAFE Investment Company Limited in China. The

\footnotetext{
${ }^{1}$ The October 1973 war between the Arab countries and Israel.

2 Currency reserves resulting from trade balance surpluses and unrelated to oil exports.
} 
2000s are undoubtedly a period of expansion of SWFs. More than 40 funds were created between 2005 and 2012. As presented in Figure 3, $11 \%$ of SWFs were created in $1950-979$ period; $40 \%$ in $2000-2009$ period and $33 \%$ of SWFs were created in 2010-2020 period.

\section{Number of SWFs created per decade}

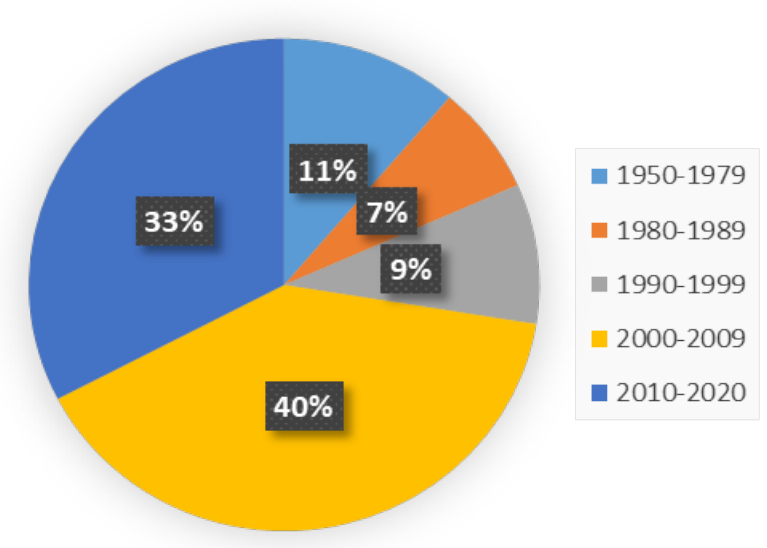

Figure 3. SWFs evolution (Source, author's calculations based on SWFI data updated on July 2020)

The creation of funds originating from countries considered significant geopolitical players, notably China ${ }^{3}$ and Russia, characterized this period. The majority of funds created in this period are financed commodity revenues following the oil price spikes due to: a) the lack of production and exportation after the invasion of Kuwait and Iraq in the early 2000s; b) the expansion of oil demand from Asian countries in the mid-2000s; and c) the Asian crisis in the 1990s and d) the Arab Spring crisis which began in $2011^{4}$. Figure 4 shows that the increase in foreign exchange reserves has enabled countries, particularly in Asia, to establish their non-commodity SWFs.

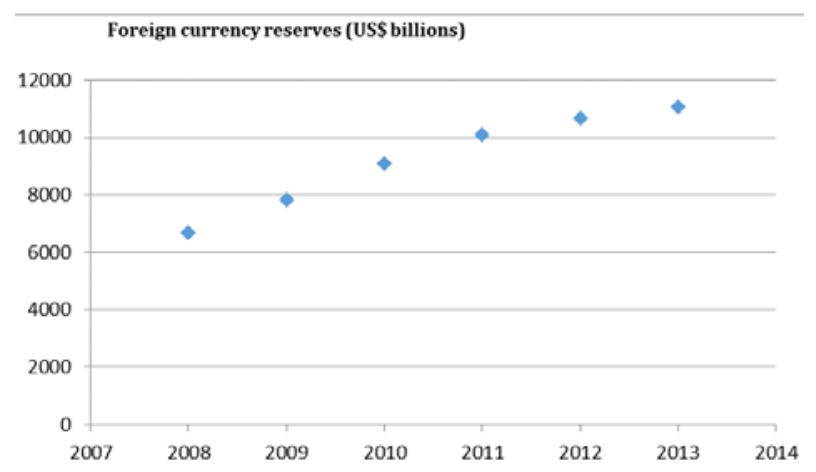

Figure 4. Evolution of the foreign exchange reserve (\$ US billions) (Source, author's calculations based on IMD World Competitiveness Center data)

\footnotetext{
${ }^{3}$ China Investment Corporation (CIC), which is the largest Chinese fund with assets under management estimated at more than $\$ 940$ billion, like most Asian countries, finances its SWF from the export of goods. In fact, increased spending and domestic investment did not follow the strong growth in Chinese production. As a result, savings were piling up.

${ }^{4}$ During the Arab Spring crisis, oil production fell, particularly in Libya.
}

By analysing the history of SWFs, we note that most established SWFs have evolved gradually in some ways from the precursors of commodity stabilization funds ([4]). The main objective of stabilization funds was to offset declines in revenues due to falling commodity prices or production levels of natural resources such as oil, copper, diamonds, or other products. Therefore, the project to create stabilization funds initially came from the countries' recognition that their resources are non-renewable and their concerns about depleting them ([5] $)^{5}$. However, stabilization funds often suffered from mismanagement and the risk of excessive political interference $([4,6])^{6}$. To reduce these risks, governments have started to promote and adopt a new fund structure. The main objective is independence from political power and a focus on maximizing financial returns, rather than limiting the damage of fluctuations in raw material prices.

Balding ([6]) distinguishes between stabilization funds, which tend to invest domestically and favor domestic development, and SWFs, which most often target the foreign market and financial returns. Bortolotti, Fotack and Megginson ([4]), for their part, believe that SWFs always keep their stabilization mandates and that the strategy of investing abroad is only a means of preventing the appreciation of the local currency and preventing "Dutch disease".

Finally, it is essential to note the evolution of the state's role in the economy with adopting this new investment vehicle. Indeed, state interference in the marketplace is far from being a new phenomenon. However, the state's economic role has evolved rapidly in recent decades ([4]). Historically, the country has always played the part of the regulator of private enterprises or the owner of enterprises called "state enterprises" (for example, Dubai Ports World or China National Offshore Oil Corporation). These public enterprises are often criticized for their mismanagement, their ineffectiveness, and their inefficiency. This situation prompted governments to follow a new privatization policy that disengages states from the business world. According to Megginson ([7]), since 1977, governments worldwide have generated more than 2.5 trillion dollars because of their privatization activity.

The paradox is that with the success of the privatization movement and criticism of state affairs, the state continues to strengthen its private activity and its engagement in the business world. However, the state follows another strategy of interference in the global economy by acting as an investor and not as an owner. States or countries target the foreign market and increasingly risky financial assets

\footnotetext{
5 The creation of sovereign wealth funds limits the dependence of countries on natural resource rents and makes it possible to keep part of the natural wealth for future generations. Likewise, countries such as China have established funds to protect themselves from fluctuations in the export prices of their goods.

${ }^{6}$ Politicians can intervene to divert assets, promote personal interests or promote excessive domestic spending.
} 
with a long-term investment horizon. This strategy is called state capitalism ([8]). Therefore, SWFs are unique entities that bring together the world of private business and state investment. Reconciling these two worlds with different objectives constitutes the most significant challenge for SWFs.

\section{Sovereign Wealth Funds: Definitional Issues}

A clear, precise and universal definition of SWFs still does not exist $([9,10,11,12,13,14,15])$. There is no consensus in academic literature or professional press articles as to what is an SWF. SWFs heterogeneity, hybrid nature, lack of transparency, and their resemblances to other sovereign investors explain this identification problem. Indeed, SWFs are quite complex entities. They have a sovereign origin; they are created and controlled by their sovereign states, but they act as classic private funds in their investment strategies and assets allocation. All these reasons make the task of defining them difficult. SWFs are heterogeneous and diversified ([13, 16]). They have different creation and investment objectives and other management structures. According to Sun, Li, Wang and Clark ([5]), each fund is unique. There is no single SWF model, but SWFs carry the geopolitical heritage and local particularism of their origin countries. Consequently, the term SWF has been defined differently. Some SWF definitions are provided in Table 2.

Table 2. Definitions of Sovereign Wealth Funds

\begin{tabular}{|c|c|}
\hline & Definitions \\
\hline [17] & $\begin{array}{l}\text { "a state-owned or influenced fund that obtains its funding from foreign-currency reserves or commodity export } \\
\text { revenues, though in certain instances, government budget surpluses and pension surpluses have also been } \\
\text { transferred to SWFs." }\end{array}$ \\
\hline [18] & "SWFs are large pools of capital controlled by a government and invested in private markets abroad." \\
\hline [19] & $\begin{array}{l}\text { "SWFs are defined as special purpose investment funds or arrangements, owned by the general government. } \\
\text { Created by the general government for macroeconomic purposes, SWFs hold, manage, or administer assets to } \\
\text { achieve financial objectives, and employ a set of investment strategies, including investing in foreign financial } \\
\text { assets. The SWFs are commonly established out of balance of payments surpluses, official foreign currency } \\
\text { operations, the proceeds of privatizations, fiscal surpluses, and/or receipts resulting from commodity exports." }\end{array}$ \\
\hline [5] & $\begin{array}{l}\text { "SWFs, in nature, are government-owned or controlled funds operated as the government's investment tools, to } \\
\text { achieve a series of economic and political objectives." }\end{array}$ \\
\hline [20] & $\begin{array}{l}\text { SWFs are "(1) an investment fund rather than an operating company; (2) that is wholly owned by a sovereign } \\
\text { government but organized separately from the central bank or finance ministry to protect it from excessive political } \\
\text { influence; (3) that makes international and domestic investments in a variety of risky assets; (4) that is charged with } \\
\text { seeking a commercial return; and (5) which is a wealth fund rather than a pension fund-meaning that the fund is } \\
\text { not financed with contributions from pensioners and does not have a stream of liabilities committed to individual } \\
\text { citizens." }\end{array}$ \\
\hline $\begin{array}{l}\text { Sovereign Wealth } \\
\text { Fund Institute }^{7}\end{array}$ & $\begin{array}{l}\text { "A Sovereign Wealth Fund (SWF) is a state-owned investment fund or entity that is commonly established from } \\
\text { balance of payments surpluses; official foreign currency operations; the proceeds of privatizations; governmental } \\
\text { transfer payments; fiscal surpluses; and/or receipts resulting from resource exports. The definition of sovereign } \\
\text { wealth fund excludes, among other things: Foreign currency reserve assets held by monetary authorities for the } \\
\text { traditional balance of payments or monetary policy purposes; state-owned enterprises (SOEs) in the traditional } \\
\text { sense; government-employee pension funds (funded by employee/employer contributions); or assets managed for } \\
\text { the benefit of individuals." }\end{array}$ \\
\hline
\end{tabular}

\footnotetext{
${ }^{7}$ Source: https://www.swfinstitute.org/research/sovereign-wealth-fund
} 


\subsection{Sovereign Wealth Funds: State Resources and Private Activities}

As mentioned above, SWFs represent state capitalism. They are funded by state resources and serve state interests, but they act like private funds. Indeed, the investment strategies of SWFs seem to follow private funds. For a long time, SWFs managers have preferred a very conservative investment strategy, including gold buying and concentrated investments in US and European public debt with a short-term investment horizon. Liquidity concerns ([21]) explain this strategy. This profile has changed remarkably. Indeed, SWF portfolios increasingly contain risky asset classes with a high return rate with a long-term investment horizon ([2, 21, 22]). The explicit absence of liabilities coupled with a greater desire to maximize returns as private funds explain this transition ([21, 23]).

SWF portfolios are comprised, for the most part, of listed equities, unlisted assets, and investments in real estate. Figure 5 shows that SWFs have a preference for listed equity. In terms of their geographic diversification, figure 6 shows that SWFs have a significant and majority presence in foreign markets. However, they are starting to take an interest in local markets (predominantly Asian SWFs). According to figure 7, the regions most targeted by SWFs investments are North America, Europe, and Asia. In terms of sector diversification, SWFs are more concentrated in finance, real estate, and mining ${ }^{8}$. Note that the concentration of assets in the financial sector can be explained by the approach followed by Western banks, which appealed to the masses of money from sovereign funds during the subprime crisis. However, the negative performance of SWFs' investments in European and American banks has prompted their owners or managers to reduce the size of their investment in this sector and to shift to other better-performing areas. Indeed, SWFs are increasingly investing in the financial technology and information technology sectors. This orientation is probably a strategic choice of the states managing the sovereign funds. For example, Singapore and South Korea are investing more in the vital technology sector to encourage their countries' transfer of knowledge and technology.
Asset allocation of SWFs (in number of transactions )

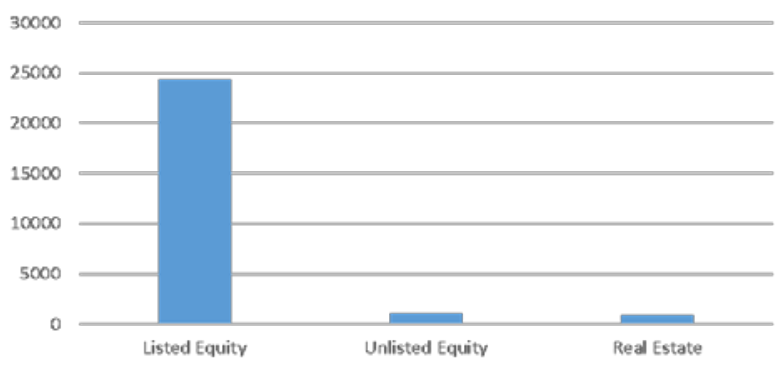

Figure 5. Asset allocation of SWFs (Source, author's calculations based on SWFI data updated on July 2020)

SWFs: Foreign versus local investments

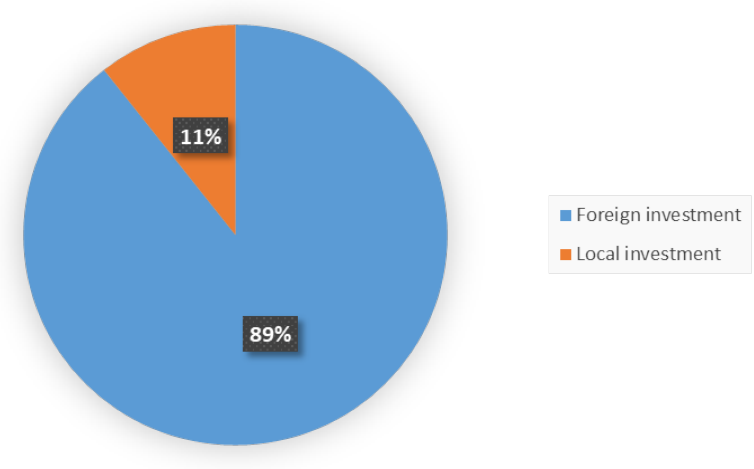

Figure 6. SWFs: Foreign versus local investments Asset (Source, author's calculations based on SWFI data updated on July 2020)

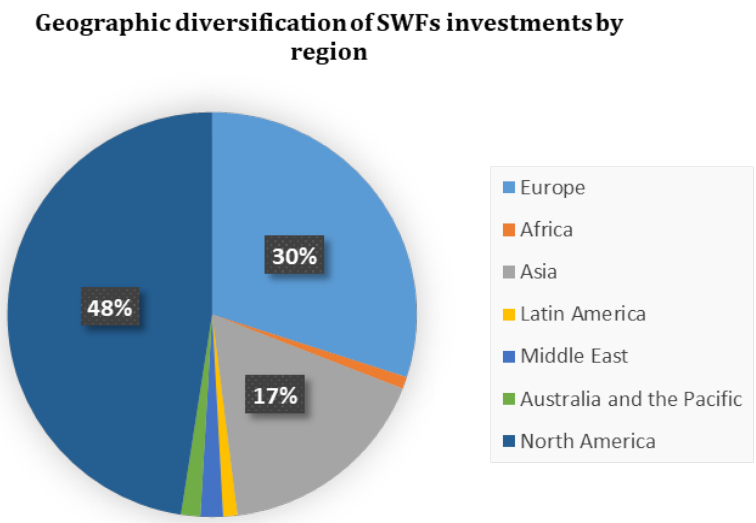

Figure 7. Geographic diversification of SWFs investments by region (Source, author's calculations based on SWFI data updated on July 2020)

\footnotetext{
${ }^{8}$ Source: https://www.swfinstitute.org
} 


\subsection{Sovereign Wealth Funds: A Heterogeneous Group}

SWFs are a heterogeneous group. They have different sources of funding, as well as different creation objectives. Aizenman and Glick ([2]) classify SWFs according to their sources of funding. They distinguish between "commodity" SWFs, which derive their origins from the exploitation or export rents of natural resources (oil, gas, phosphate, copper, diamonds, etc.). The category represents 57\% of all SWFs (typically in Middle Eastern countries like the UAE, Saudi Arabia, and Qatar). The second category, called "non-commodity" funds, is mainly financed by privatization, tax revenues, and excess foreign exchange reserves accumulated by central banks. This category represents $43 \%$ of all SWFs (typically in Asian countries like China and Singapore).

SWFs also have different creation objectives such as (1) isolating the country's budget and economy from natural resource price fluctuations ([21, 23, 24, 25]); (2) converting income from non-renewable resources into a diversified portfolio of assets to (3) optimizing the risk-return ratio and improving the overall efficiency of asset allocation ([21, 26]); (4) transferring wealth for future generations ([21]); (5) funding any unfunded retirement liabilities or other monetary requirements; (6) promoting national enterprises and industries and transfer technology and knowledge to domestic industries ([23]) and (7) increasing political influence by making foreign political investments ([27]) ${ }^{9}$. The International Monetary Fund ([28]) proposes a taxonomy of SWFs according to their objectives: stabilization funds, saving funds for future generations, reserve investment funds, development funds, and pension reserve funds.

The difficulty in defining SWFs precisely lies in their hybrid nature and heterogeneity. Moreover, the analysis of advanced definitions (see table 2) shows broad definitions that include pension funds, central banks, government investment companies, public companies, and other investment vehicles. Additional definitions are more restricted. Consequently, until now, the distinction between SWFs and other investment vehicles remains unclear, making it more difficult to agree on a standard definition of SWFs. We will now present some features that distinguish SWFs from other sovereign and private investors.

\subsection{Sovereign Wealth Funds versus Other Investor Categories}

SWFs have become significant players in international financial markets. However, their distinction from other

\footnotetext{
${ }^{9}$ While the first five goals may lead to investment models similar to those of other institutional investors, the last two are not consistent with maximizing profits. These two factors suggest that SWFs can act separately from institutional investors.
}

types of sovereign investors (state enterprises, foreign exchange reserves held by the central bank), and other private investors such as pension funds is still unclear. For some specialists, an SWF is only one type of government investor among others ([24]), while for others, the distinction between sovereign funds and other public investment entities is crucial ([1, 17, 29, 30]). Kimmit ([18]) argues that fears and concerns about sovereign investments are due to misconceptions of SWFs and their differences with sovereign investors. Therefore, identifying these entities and their dissimilarities is helpful.

We must admit that the differences are subtle and the distinction between SWFs and other state entities is quite complicated due to the complexity and diversity of SWFs and the close resemblance between the different types of state investors, as they share state origin and national objectives and are all mainly active in international markets.

\subsubsection{Sovereign Wealth Funds}

The definition advanced by Megginson and Fotack ([20]) clarifies certain differences between state entities. A sovereign wealth fund (1) is "an investment fund rather than an operating company; (2) is wholly owned by a sovereign government, but organized separately from the central bank or the finance ministry to protect it from excessive political influence; (3) makes international and domestic investments in a variety of risky assets; (4) [has for] objective [...] to maximize returns on investments; (5) is a savings fund rather than a pension fund - which means that the fund is not financed by contributions from retirees and has no future liabilities to individuals."

Therefore, the difference between SWFs, state-owned enterprises, central bank foreign exchange reserves, and pension funds lies mainly in their structure, mission, governance, investment strategy, and funding source. Moreover, Bismuth ([31]) summarizes the differences between sovereign wealth funds and state entities in their structural ties to the state and their private investment activities for public purposes.

The state finances sovereign wealth funds primarily through commodity income, privatization income, and excess foreign exchange reserves accumulated by central banks, which come from large surpluses in the balance of payments. We should note that central banks only transfer excess foreign currency reserves to SWFs. They do not need to fulfill their mission of preventing and protecting their countries against macroeconomic crises. So, at this point, we can see the difference between SWFs and the central bank's foreign exchange reserves. We can also distinguish between SWFs and pension funds since the latter are funded by employees and employers' contributions and not from state resources.

But SWFs are funds and not operating companies like Crown corporations. They are created and controlled by the state while having a private purpose. Indeed, their activities 
aim at public investments accessible to any individual ([31]). These investments target more risky abroad assets, whose objective is to maximize their return.

\subsubsection{Central Banks and Foreign Exchange Reserves}

The central bank is a state institution that manages and controls foreign exchange reserves for monetary policy purposes. The central bank's objective is to cushion the export deficit and defend the national currency in crisis times. To do this, the central bank invests foreign currency reserves in liquid and risk-free securities to facilitate the availability of funding for emergencies and crises (often, the central bank targets highly rated government bonds such as the United States treasury bills). Unlike the central bank, SWFs tend to prefer returns over liquidity since they have a higher tolerance for risk than traditional foreign exchange reserves ([32]). Note that, in the context of excess foreign currency, the central bank can inject this surplus to finance its country's SWF. Finally, and like SWFs, central bank investments can also raise concerns about their political investment objectives ([17]).

\subsubsection{State-Owned Enterprise (SOE)}

Despite the trend towards liberalization of markets and privatization, SOEs have experienced a remarkable international expansion in recent years. For example, Dubai Ports World attempted to acquire P \& O Cruises, which operated several US ports. The China National Offshore Oil Company Ltd. tried to buy the US company Unocal in 2006 as well as the Aluminum Corporation of China (Chinalco) who bought 9\% of the Rio Tinto PLC shares in 2008.

SOEs are companies over which the state exercises significant control through minority ownership or full, majority, or considerable ownership ([18]). They are not a "fund" and were not created to invest in other entities. However, an SOE could engage in such activities and could also invest abroad $([17,18])$. But when they do so, SOEs do not act like SWFs as investors who buy non-controlling stakes in foreign and domestic firms to achieve long-term financial returns. They act like owners who own and operate these businesses to maximize their operations ([17, $20,33])$.

Moreover, SOEs differ from SWFs in their sources of funding. Typically, SOEs are financed by their activities' proceeds, although some are fueled by foreign exchange reserves ([34]). SOEs are mainly focused on their respective industries. Furthermore, confusion exists between the different categories of SWFs:

Reserve funds for pensions such as the Norwegian Government Pension Fund-Global: Public pension funds are sovereign investment vehicles whose objective is to finance pension payments by diverting part of the current returns from natural resource production to these funds.

Sovereign Wealth Enterprises [SWEs] such as the St-Martins Property Group: According to the SWFI, sovereign wealth companies are investment vehicles owned and controlled by sovereign wealth funds. The use of these subsidiaries as intermediaries allows greater flexibility for SWFs. A state enterprise can be considered a sovereign wealth enterprise if it is directly under the control of a sovereign wealth fund.

Other than sovereign investors, a distinction must be made between SWFs and traditional institutional investors (pension funds, mutual funds, hedge funds, etc.) ([20,32]). If the SWFs were just a large financial investor with economic interests, there would be no fear about their investments and no reason to establish regulatory barriers to their foreign sector activities. Besides, there would be no use or interest in studying their impacts on financial markets ([20]).

According to the literature, there are similarities and differences in organizational structure, corporate governance system, and investment models and motives between SWFs and institutional investors. The significant similarity between these two types of investors is the private nature of their activities ([31]). Also, Kotter and Lel ([14]) confirm that SWFs resemble passive institutional investors in terms of investment choices. They find that SWFs investors are attracted to large firms that operate internationally. Megginson, You, Han ([13]) argue that SWFs are not fundamentally different from other activist investors' funds internationally, such as pension funds and mutual funds. They add that SWFs, like hedge funds, are unregulated, are managed by professionals, and often take large stakes in target firms with a high tolerance for risk. Knill, Lee, and Mauck ([27]) argue that SWFs behave like mutual funds in their investment strategies.

However, there are significant differences between SWFs and private institutional investors:

(1) the structural attachment of sovereign funds to the originating state. In short, the main feature that makes SWFs genuinely different is their governmental nature; indeed, sovereign wealth funds are created, owned, and funded by state resources ([20, 30, 31]).

(2) The size of the assets. According to the Sovereign Wealth Fund Institute, SWFs today manage more than US\$8 trillion in assets, a considerable size compared to hedge funds and private equity funds. However, this size remains limited compared to the total value of financial assets worldwide, estimated at 223 trillion dollars in 2012 by McKinsey \& Company ([20]).

(3) The investment objectives. Although SWFs often claim that their investment objective is to maximize wealth, the fact remains that these entities are state-owned. Therefore, SWFs could have geopolitical and strategic goals, such as the transfer of know-how from sensitive sectors. The fact that SWFs might have political interests could cause them to behave differently from other institutional investors. Moreover, Chhaochharia and Laeven ([35]) and Kotter and Lel ([14]) show that, unlike institutional investors, SWFs are attracted to firms facing 
financial difficulties and countries affected by the financial crisis. Knill, Lee, and Mauck ([36]) find that SWFs prefer to invest in countries with weak political relations, contrary to foreign direct investment theory.

Generally, pension funds are the only natural analog of SWFs in terms of their objectives. Some SWFs' mission is to preserve wealth for future generations ([36]). Also, Chhaochharia and Laeven ([35]) suggest that pension funds have the same investment horizons and target the same asset classes. However, they differ in their objectives, investment strategies, transparency, and sources of funding.

(4) The difference in corporate governance structures. As for governance, Ferreira and Matos ([37]) show that institutional investors are involved in the ongoing surveillance activity of target companies worldwide. However, SWFs generally follow passive strategies to avoid attracting public and governmental interest, even if they sometimes act like activist investors ([38]). Besides, SWFs are widely known for their opacity compared to other types of investors (except for hedge funds, also known for their lack of transparency). Moreover, Avendano and Santiso ([32]) conducted an in-depth comparison between SWFs and pension funds based on Truman's governance rating (2008). They found that the pension funds are superior concerning all criteria. They display higher levels of transparency, and their investment strategies are more precise and more defined.

(5) Sources of funding. Another difference is the sources of financing. For example, pension funds (e.g., Calpers and the Fonds de Réserve des Retraites in France) are funded by employee contributions (paid by employees or their employers), while government resources fund SWFs.

(6) Information superiority. In the local market and given the SWFs government attachment, they may have an information edge over other investors. For example, SWFs may be the first to know before the market if there are regulatory changes relative to a particular industry or changes that may affect targeted firms' value.

(7) Finally, SWFs have no future commitments or obligations to fulfill towards individuals like pension funds, which have responsibilities towards contributors $([39,40])$. SWFs have the opportunity to invest in long-term investment horizons.

Between the similarities and the differences, SWFs are particularly interesting. They present state objectives and private fund peculiarities: this is called state capitalism.

\subsection{Sovereign Wealth Funds: Transparency Issues}

Lack of transparency of SWFs is another principal reason for a definitional problem. Indeed, we cannot precisely define an entity when we know little about its structure, governance, and investment strategies. Figure 8 which illustrates the degree of transparency of SWFs by country as defined by The Linaburg-Maduell transparency index. The latter is a method of rating transparency in respect to sovereign wealth funds developed by SWF Institute. The index varies from 0 to 10 , high values are assigned to sovereign wealth funds with higher transparency levels and low values are assigned to sovereign wealth funds with lower transparency levels. Figure 8 indicates that many of these funds are quite secretive (Brunei Investment Agency, Kazakhstan national Fund, etc.). The most transparent funds tend to be those from the most developed, democratic, and stable markets (for example, Norway Government Pension Fund Global and Alaska Permanent Fund Corporation). Figure 9 shows that the level of transparency of SWFs is higher than that of government policies in their countries of origin. We believe that despite the opacity of SWF countries of origin, SWFs are trying to approach private funds regarding their transparency level.

\section{Transparency level of SWFs by country}

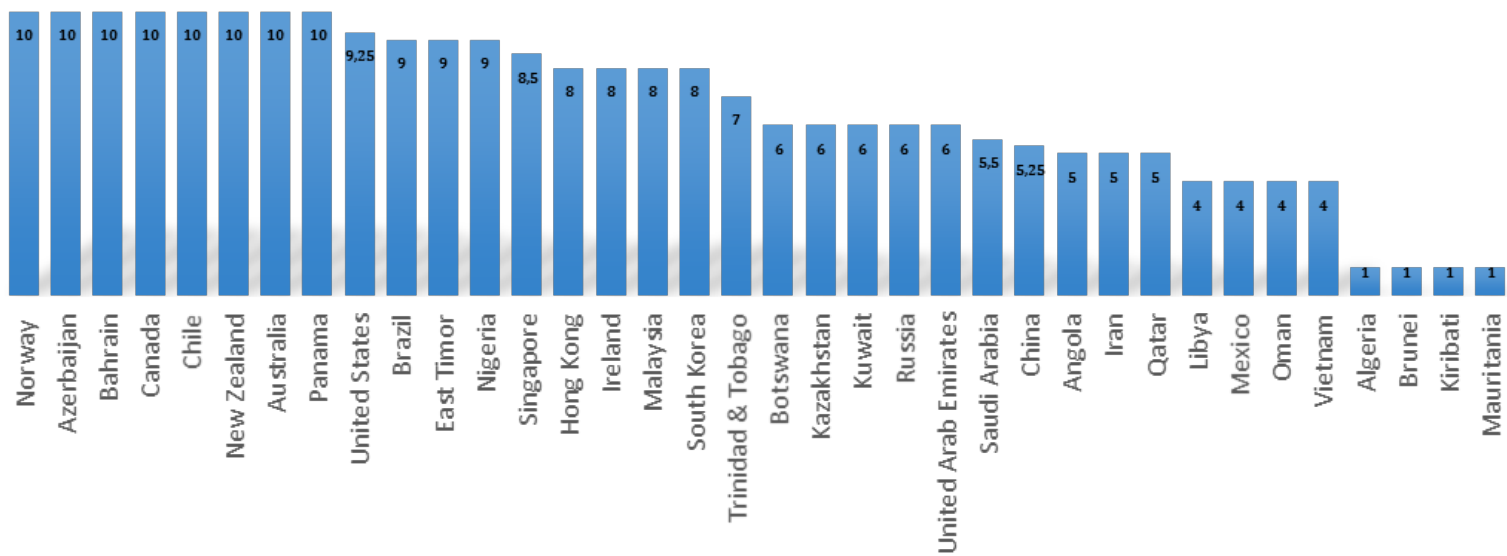

Figure 8. Transparency of SWFs by country (Source, author's calculations based on SWFI data updated on July 2020) (We have calculated the average per country of the Linaburg-Maduell transparency index published by SWFI, 2020). 


\section{SWFs versus government policy transparency by country}

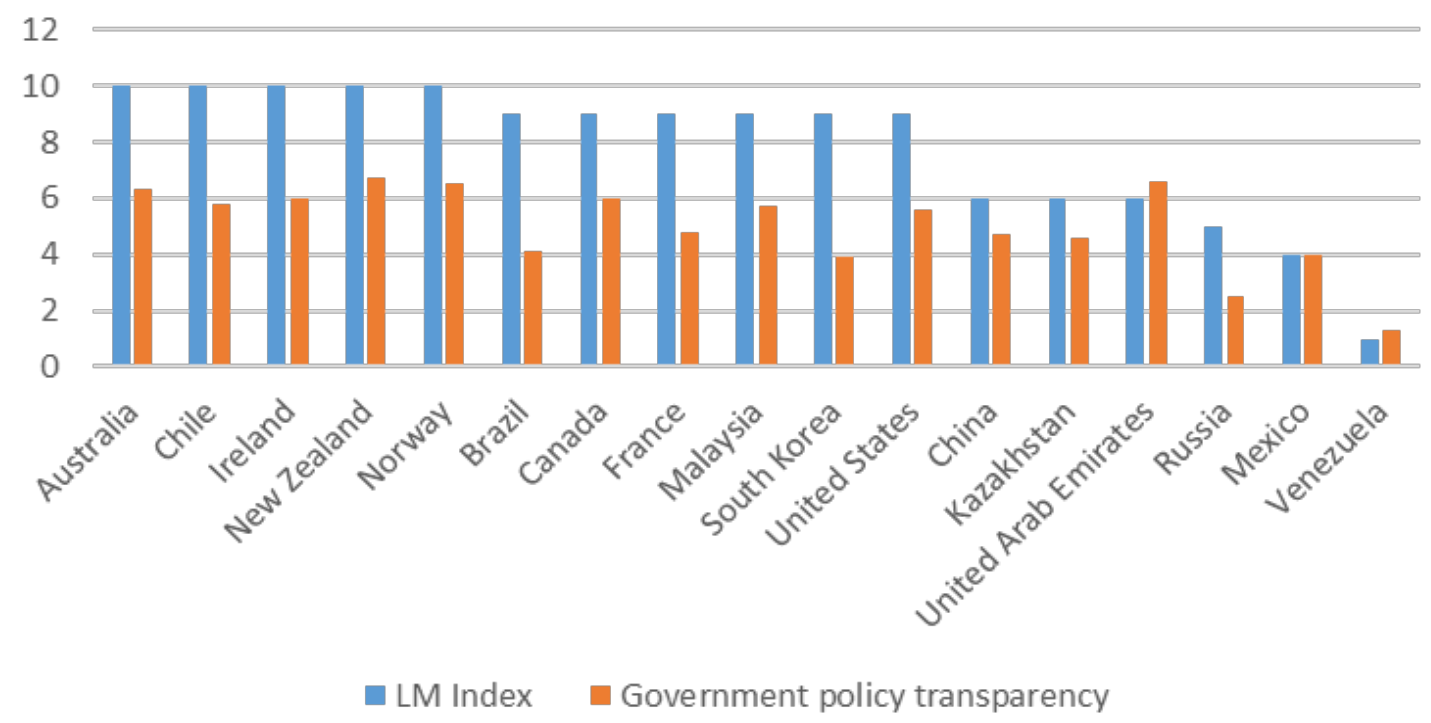

Figure 9. SWFs versus government policy transparency by country (Source, author's calculations based on SWFI data (July 2020) and IMD World Competitiveness Center data)

To improve SWFs' transparency, the International Monetary Fund has published a good practice code for SWFs called the Santiago Principles. In 2008, a meeting of 25 countries with SWFs in Santiago led to the Santiago Principles. The signatories have committed to greater voluntary transparency. Here are some of these principles: (1) The investment objectives of SWFs should be purely economic. SWFs should make this declaration formally as part of their investment policy; (2) SWFs should commit to greater transparency for their investment objective and financial reporting; (3) SWFs should have governance structures, internal controls, and operational and risk management systems; (4) SWFs must comply with the host country rules by complying with all regulatory and information requirements applicable in the countries where they invest.

Following a July 7, 2011 meeting, the International Sovereign Wealth Fund Forum (IFSWF) released a report on its members' experience in applying the Santiago Principles. The report is a self-assessment of 21 SWFs members' voluntary compliance with the generally accepted SWF principles and practices published in October 2008. Although SWFs have improved their transparency voluntarily (like the ADIA, the Abu Dhabi Investment Authority), it remains that, in practice, the principles have been applied relatively little.

Two measures of transparency and internal governance of SWFs are regarded as standards and have been universally used and adopted by professionals and academics. The first measure is the Linaburg-Maduell Transparency Index (LMTI), developed by Carl Linaburg and Michael Maduell and utilized by the SWFI. The second measure is the SWF Scoreboard, known as "Truman Scores". The two scales are quite similar in terms of the amount of information they disclose and the level of funds transparency.

The Linaburg-Maduell transparency index ranges from 0 to 10. The index is based on the adoption of the best practices for information transparency. Higher L-M index values are associated with more transparent backgrounds. According to this index, the least open funds (index $=1$ ) are the Kiribati Revenue Equalization Reserve Fund, the Brunei Investment Agency, the Algerian Revenue Regulation Fund, and the Mauritania National Fund for Hydrocarbon Reserves. The most transparent funds (index = 10) are the Government Pension Fund of Norway, Temasek Holdings Private Limited, the Alaska Permanent Fund, the Ireland Strategic Investment Fund, and others (see Table 1).

As for the Truman index, it gives ratings to the following elements classified into four categories: (1) the structure of the fund, including its objectives; (2) the fund governance; (3) the fund accountability and transparency; and (4) the fund behavior for the management of its portfolio and its risk management policies. The Truman score ranges from 0 (opaque) to a maximum of 100 (transparent), and the highest rating awarded in 2015 is 98, for the Government Pension Fund of Norway. Truman added another measure of the quality of transparency and governance for SWFs representing the degree of compliance of SWFs with the Santiago principles adopted in September 2008.

In summary, the challenge of defining SWFs lies in their hybrid nature, heterogeneity, similarities with sovereign and private investors, and their lack of transparency. This issue is aggravated by SWFs' concerns, the ambiguity of their investment objectives, and lack of regulatory compliance. As a result, countries receiving their investment are forced to increase the control and 
monitoring of SWFs and limit the number, size, and sectors they can invest. Consequently, this means the return protectionist policies with their known negative consequences on the global economy.

\subsection{Sovereign Wealth Funds: Major Concerns}

Several questions and concerns have been raised about the implicit motivations of the SWFs' investments and their impact on the international financial system's functioning and the countries' sovereignty and national security benefiting from their investments. The lack of a clear and precise definition of SWFs increases ambiguity and doubt surrounding their nature, size, investment strategies, and objectives, presenting a serious matter for academics and market regulators. Indeed, how are we to initiate regulatory policies on entities whose nature are not known precisely?

Concerning empirical papers on SWFs, the results are often inconclusive and divergent. In fact, several studies have examined the SWF's investment choices and performance. According to Boubakri, Cosset and Grira ([42]) and compared to pension funds, SWFs prefer to invest in countries with greater economic growth and weaker legal and institutional environments. Kotter and Lel ([14]) argue that SWFs are similar to passive institutional investors in their investment choices. The authors show that transparent SWFs prefer to invest in large firms with financial difficulties. Similarly, Fernandes ([39]) finds that SWFs are more likely to target larger firms. According to Debarsy, Gnabo and Kerkour ([43]) SWF target developed markets and politically stable countries with higher GDP per capita. Whereas Chhaochharia and Laeven ([35]) documented that SWFs invest more in countries with which they have cultural similarities.

While for empirical studies examining SWF's investment performance, the results are even more divergent, especially for long-term performance. Bortolotti, Fotak, and Megginson ([12]), reports that market reactions to SWF investments are positive but lower than those of comparable private institutional investors by approximately $1.31 \%$. As well as, Knill, Lee and Mauck ([27]) and Chhaochharia et Laeven ([35]) argue that SWFs investment are associated with deteriorating long-term performance of target firms. While, Fernandes ([35]) find that SWF investments improve the long-term performance of target firms. In addition, we have to note that SWF's investment performance depend on the origin, size and level of transparency of funds ([16]). The latter confirm that the divergence of empirical research results and the difference in SWFs' transactions number and value are due to the different definitions of SWFs.

Therefore, accurately defining SWFs remains a significant challenge for analysts and researchers trying to understand the phenomenon better and provide solid bases and references for adequate regulation of their investments. Until now, no consensus exists on the rules for SWFs.
Regulatory policies exist regarding foreign investors in general, but they don't apply correctly to SWFs. To prevent their investments' negative impact, some scholars and observers have called for an agreement on a set of best practices and guidelines for SWFs ([41]). As such, the first agreement for ethical practices of sovereign wealth funds was announced in early September 2008 (Santiago principles). Others suggest strengthening regulation and protectionist practices to mitigate threats from SWFs. For example, France and Australia have decided to define prohibited sectors for sovereign funds. Other countries have proposed limiting SWFs' participation to non-voting stocks or blocking attempts at significant involvement (Germany and Japan). However, others prevent the recall of negative consequences of protectionist practices. Kimmit ([18]) argues that fears and concerns about SWFs are exaggerated, partly because of a lack of understanding of SWFs and their differences with sovereign investors. Therefore, identifying these entities and their differences is helpful to reassure and calm concerns about SWFs.

\section{Conclusions}

In recent years, sovereign wealth funds have become significant players in the international financial markets. They continue to make headline news due to their substantial assets and growing number. For example, the Norwegian fund, Government Pension Fund-Global, the largest SWF in the world with estimated assets under management of over US $\$ 1100$ billion, is present in over 9 000 companies and controls the equivalent of $1.4 \%$ of global market capitalization. Furthermore, academics and market regulators are increasingly interested in reviewing SWF investments. Indeed, SWF investments can increase the risk level since their transactions could be motivated by political and not economic objectives. Despite this rise in interest, SWFs are misunderstood. They do not have a standard and universally accepted definition yet. By analyzing their history, structures, and specificities, we conclude that the lack of a standard definition is due to their hybrid nature, heterogeneity structure, lack of transparency, and their similarities with other sovereign and private investors as state-owned enterprises or pension funds. Because of these definitional issues, existing empirical studies are based on different sample sizes, different values of SWFs, and different values and numbers of their deals, which explains the divergence in empirical studies' results. So, we cannot conclude with a certainty of their motives and impacts. All these issues could also concern the market regulators who are trying to regulate their investments. This paper underlines the issue of defining SWFs and we call to take into account the heterogeneity of these funds, which will help academics and market regulators to examine and regulate these state vehicles' investments. The following diagram summarizes the contents of this paper. 


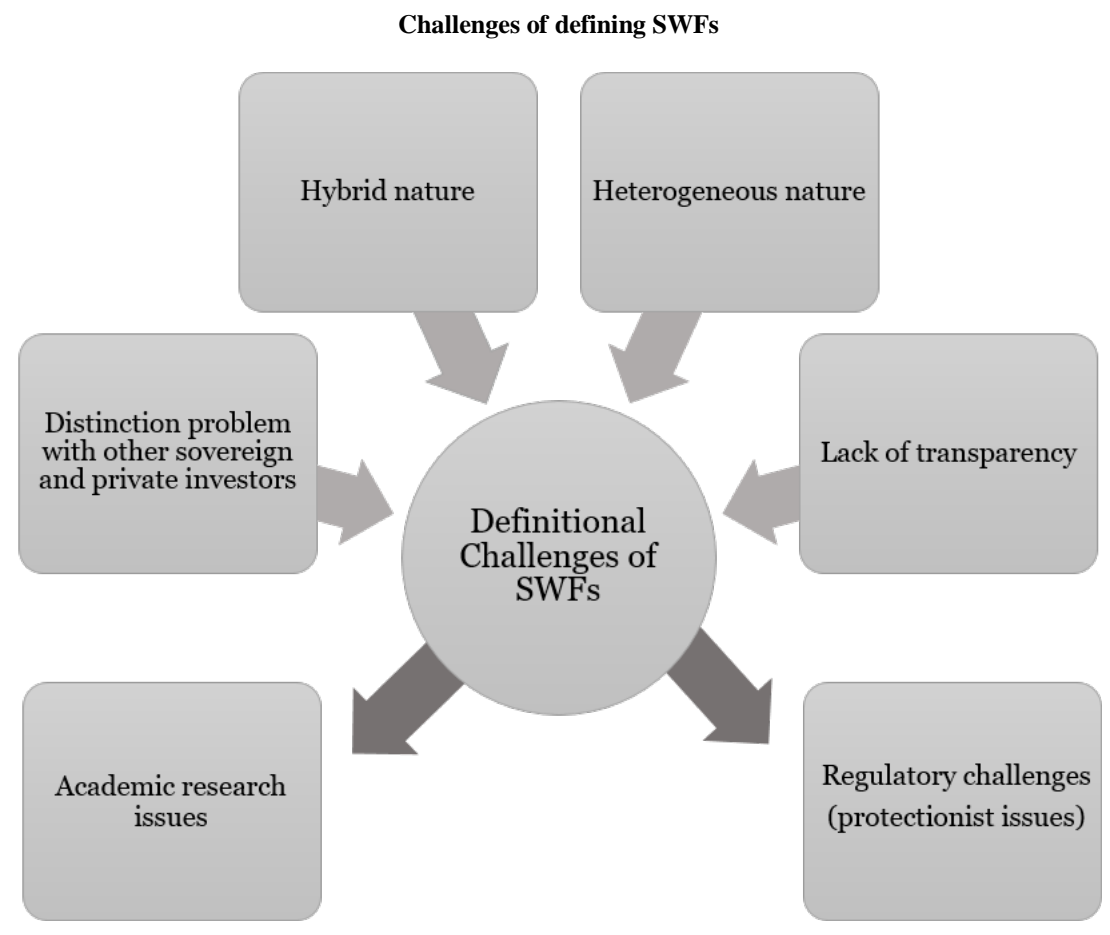

\section{REFERENCES}

[1] Rozanov A., "Who Holds the Wealth of Nations?," Central Banking Quarterly Journal, vol. 15, no. 4, pp. 52-54, 2005.

[2] Aizenman J., R. Glick, "Sovereign Wealth Funds: Stylized Facts about their Determinants and Governance," International Finance, vol.12, no.3, pp. 351-386, 2009. DOI: 10.3386/w14562

[3] Dedu V., D.C. Nițescu, "Sovereign Wealth Funds, Catalyzers for Global Financial Markets," Theoretical and Applied Economics, vol. XX, no.2, pp. 7-18, 2014.

[4] Bortolotti B., Fotak V., W.L. Megginson, "The Rise of Sovereign Wealth Funds: Definition, Organization, and Governance Public-Private Partnerships for Infrastructure and Business Development," in Caselli S., Corbetta G., Vecchi V. (eds) Public Private Partnerships for Infrastructure and Business Development, Palgrave Macmillan, 2015a, pp. 295-318. https://doi.org/10.1057/97 $81137541482 \_16$

[5] Sun X., Li J., Wang Y., W.W. Clark, "China's Sovereign Wealth Fund Investments in Overseas Energy: The Energy Security Perspective," Energy Policy, vol. 65, pp. 654-661, 2014. https://doi.org/10.1016/j.enpol.2013.09.056

[6] Balding C., "Innovations in Sovereign Wealth Funds for National Development", SSRN, https://papers.ssrn.com/sol 3/papers.cfm?abstract_id=2121005 (accessed July. 16, 2020).

[7] Megginson W.L, "Privatization Trends and Major Deals in 2012 and 2013", SSRN, https://ssrn.com/abstract=2311798 (accessed April. 10, 2020).

[8] Gilson R.J., C.J. Milhaupt, "Sovereign Wealth Funds and
Corporate Governance: A Minimalist Response to the New Mercantilism, Stanford Law Review, vol. 60, no.5, pp. 1345-1369, 2008. https://www.jstor.org/stable/40040388

[9] Amar J., Candelon B., Lecourt C., Z. Xun, "Country factors and the investment decision-making process of sovereign wealth funds, " Economic Modelling, vol. 80, pp. 34-48, 2019. https://doi.org/10.1016/j.econmod.2018.04.008

[10] Park R.J., Xu S., In F., P.I. Ji, "The long-term impact of sovereign wealth fund investments," Journal of Financial Markets, vol. 45, pp.115-138, 2019. https://doi.org/10.1016 /j.finmar.2018.08.004

[11] Akyol M., Y.B. Çiçen, "The role of institutional factors when determining investment strategies of sovereign wealth funds in stock market," Turkish Economic Review, vol. 4, no.3, pp. 334-342, 2017.

[12] Bortolotti B., Fotak V., W.L. Megginson, "The Sovereign Wealth Fund Discount: Evidence from Public Equity Investments, " The Review of Financial Studies, vol. 28, no. 11, pp. 2993-3035, 2015b. https://doi.org/10.1093/rfs/hhv0 36

[13] Megginson W.L, You M., L. Han, "Determinants of Sovereign Wealth Fund Cross-Border Investments," The Financial Review, vol. 48, no.4, pp. 539-572, 2013. DOI: 10.1111/fire.12015

[14] Kotter J., U. Lel, "Friends or Foes? Targets Election Decisions of Sovereign Wealth Funds and their Consequences, "Journal of Financial Economics, vol. 101, pp. 360-381, 2011. DOI: 10.2139/ssrn.1292407

[15] Rozanov A., "Definitional Challenges of Dealing with Sovereign Wealth Funds," Asian Journal of International Law, vol. 1, no.2, pp. 249-265, 2011. DOI: $10.1017 /$ S2044251310000081

[16] Megginson W.L., X. Gao,"The state of research on sovereign wealth funds," Global Finance Journal, vol.44, 
2020, https://doi.org/10.1016/j.gfj.2019.03.003

[17] Greene E.F., B.A. Yeager, "Sovereign Wealth Funds-A Measured Assessment, " Capital Markets Law Journal, vol. 3, no.3, pp. 247-274, 2008. https://doi.org/10.1093/cmlj/km n011

[18] Kimmitt R.M, "Public Footprints in Private Markets: Sovereign Wealth Funds and the World Economy, " Foreign Affairs, vol. 87, no. 1, pp. 119-130, 2008. https://www.jstor.org/stable/20020272

[19] IWG, "Sovereign Wealth Fund: Generally Accepted Principles and Practices «Santiago Principles»", IFSWF, https://www.ifswf.org/sites/default/files/santiagoprinciples_ 0_0.pdf (accessed October. 04, 2020).

[20] Megginson W.L., V. Fotak, "Rise of the Fiduciary State: A Survey of Sovereign Wealth Fund Research, " Journal of Economic Surveys, vol. 29, no.4, pp. 733-778, 2015. DOI: $10.2139 /$ ssrn.2432623

[21] Moshirian F., "Sovereign Wealth Funds and Sub-Prime Credit Problems", SSRN, https://papers.ssrn.com/sol3/pape rs.cfm?abstract_id=1275226 (accessed October.6, 2020)

[22] Beck R., M. Fidora, "The Impact of Sovereign Wealth Funds on Global Financial Markets, "Intereconomics, vol.43, no.6, 349-358, 2008. DOI: 10.1007/s10272-008-0268-5

[23] Balin B.J, "Sovereign Wealth Funds: A Critical Analysis", SSRN Online Journal, 2009. DOI: 10.2139/ssrn.1477725

[24] Truman E.M., "Sovereign Wealth Funds: The Need for Greater Transparency and Accountability, " AFI, http://www.afi.es/EO/Sovereign\%20Funds\%20Peterson\%2 007.pdf (accessed October. 7, 2020)

[25] Gomes T., "The Impact of Sovereign Wealth Funds on International Financial Stability,", BANK OF CANADA, https://www.bankofcanada.ca/wp-content/uploads/2010/01/ dp08-14.pdf (accessed October. 7, 2020)

[26] Rose P., "Sovereign Wealth Funds: Active or Passive Investors?, "Yale Law Journal Online, vol. 118, 104-108, 2008. SSRN, https://papers.ssrn.com/sol3/papers.cfm?abstr act_id=1307182 (accessed October. 7, 2020)

[27] Knill A.M., Lee B.S., N. Mauck, "Sovereign Wealth Fund Investment and the Return-to-risk Performance of Target firms, " Journal of Financial Intermediation, vol. 21, no.2, pp. 315-340, 2012a. https://doi.org/10.1016/j.jfi.2011.10.001

[28] IMF, "Fonds souverains : le FMI intensifie ses travaux", IMF, www.imf.org (accessed October. 7, 2020)

[29] Haghighi A.H., "Sovereign Wealth Funds Efficiency in Iran (Economic Law Solution)", SSRN, https://papers.ssrn.com/ sol3/papers.cfm?abstract_id=2592877(accessed October. 7, 2020)

[30] Ciarlone A., V. Miceli, "Are Sovereign Wealth Funds Contrarian Investors?", SSRN, https://papers.ssrn.com/sol3/ papers.cfm?abstract_id=2550736 (accessed October. 7, 2020)

[31] Bismuth R., "Les Fonds souverains face au droit international. Panorama des problèmes juridiques posés par des investisseurs peu ordinaires", Annuaire français de droit international, vol. 56, no.1, pp. 567-606, 2010. Persee, https://www.persee.fr/doc/afdi_0066-3085_2010_num_56_ 1_4627 (accessed October. 7, 2020)

[32] Avendano R., J. Santiso, "Are Sovereign Wealth Funds Politically Biased? A Comparison with other Institutional Investors," in N. Boubakri, J.C. Cosset. (eds), Institutional Investors in Global Capital Markets, Emerald Group Publishing Limited, 2011, pp. 313 - 353.

[33] Backer L.C., "Sovereign Wealth Funds as Regulatory Chameleons: The Norwegian Sovereign Wealth Funds and Public Global Governance Through Private Global Investment, " Georgetown Journal of International Law, vol. 41, no.2, 2009. SSRN, https://papers.ssrn.com/sol3/papers.c fm?abstract_id=1398835 (accessed October. 7, 2020)

[34] Sauvant K.P., Sachs L.E.,W.P.F. Schmit Jongbloed, "Sovereign Investment: Concerns and Policy Reactions," Oxford University Press, 2012.DOI:10.1093/acprof:osobl/9 780199937929.001.0001

[35] Chhaochharia V., L. Laeven, "The Investment Allocation of Sovereign Wealth Funds," SSRN, https://papers.ssrn.com/s ol3/papers.cfm?abstract_id=1262383 (accessed October. 7, 2020)

[36] Knill A.M., Lee B.S., N. Mauck, "Bilateral Political Relations and Sovereign Wealth Fund Investment," Journal of Corporate Finance, vol.18, no. 1, pp.108-123, 2012b. https://doi.org/10.1016/j.jcorpfin.2011.11.002

[37] Ferreira M.A., P. Matos, "The Colors of Investors’ Money: The Role of Institutional Investors Around The World, " Journal of Financial Economics, vol. 88, no.3, pp. 499-533, 2008. https://doi.org/10.1016/j.jfineco.2007.07.003

[38] Mietzner M., Schiereck D., D. Schweizer, "The Role of Sovereign Wealth Funds as Activist or Passive Fund Managers," SSRN, https://papers.ssrn.com/sol3/papers.cfm ?abstract_id=2653371 (accessed October. 7, 2020)

[39] Fernandes N., "The Impact of Sovereign Wealth Funds on Corporate Value and Performance, "Journal of Applied Corporate Finance, vol. 26, no.1, pp. 76-84, 2014. DOI: 10.1111/jacf.12056

[40] Johan S.A., Knill A., N. Mauck, "Determinants of Sovereign Wealth Fund Investment in Private Equity Vs. Public Equity," Journal of International Business Studies, vol. 44, no.2, 2013. https://www.jstor.org/stable/23434175

[41] Truman E.M., "A Blueprint for Sovereign Wealth Fund Best Practices," Revue d 'économie financière, vol. 9, no. 1, pp.429-451, 2008. DOI: 10.3406/ecofi.2009.5526

[42] Boubakri, N., Cosset, J. C., J. Grira, "Sovereign wealth funds targets selection: A comparison with pension funds, " Journal of International Financial Markets, vol. 42, pp.60-76, 2016. https://doi.org/10.1016/j.intfin.2016.01.004

[43] Debarsy, N., Gnabo, J. Y., M, Kerkour, "Sovereign Wealth Funds' cross-border investments: Assessing the role of country-level drivers and spatial competition, "Journal of International Money and Finance, vol. 76, pp. 68-87, 2017. https://doi.org/10.1016/j.jimonfin.2017.05.007 